\title{
Изучение номеров конкурсного сортоиспытания нута по хозяйственно- ценным признакам в сухостепной зоне Алматинской области
}

Байтаракова К.Ж., с.н.с.; Кудайбергенов М.С., д.б.н.; Нусипбай К., н.с.; Абилдаева Д.Б., м.н.с.

Казахский научно-исследовательский институт земледелия и растениеводства, п. Алмальгбак, Казахстан.

e-mail: kuralai_baitarakova@mail.ru

Изучены селекиионные номера нута в питомнике конкурсного сортоиспытания. За период исследования были выделены номера, которые по урожайности превзошли стандартный сорт Камила 1255. В 2017 году сорт Cәтті (F02-04) был передан в ГКСИСК на Государственное сортоиспытание.

Ключевые слова: нут, сорт, номер, продуктивность.

The study of samples competitive variety trials of chickpea on economic valuable signs in the dry-steppe zone of Almaty region

Baitarakova K. J., Senior researcher, Kudaibergenov M. S., Doctor of Biological Sciences, Nusipbai K., Researcher, Abildayeva D. B., Junior Researcher. LLP "Kazakh Scientific Research Institute of Agriculture and Plant Growing" (LLP "KazNIIZiR"), Almaty, Kazakhstan

We studied the selection numbers of chickpeas in the nursery of competitive variety testing, in a conditional study and these numbers exceeded the standard variety Kamila 1255. In 2017, they were Satti (F02-04) and transferred to the SACVTAC for State variety testing.

Key words: Chickpeas, variety, number, productivity.

Ценность зерновых бобовых культур определяется, прежде всего, высоким содержанием хорошо усвояемого белка в семенах и других органах $[1,2]$. Важной задачей для Казахстана на сегодня является обеспечение сбалансированного питания людей белковыми продуктами растительного происхождения. Ведутся работы по созданию новых высокоурожайных и конкурентоспособных сортов зернобобовых культур, но в основном привезенные зарубежные сорта не приспособлены к нашим почвенноклиматическим условиям, поэтому мы должны создавать отечественные сорта с высокими хозяйственно-ценными признаками и с высокой урожайностью.

Зерно нута - ценный источник минеральных веществ, витаминов и других биологически ценных веществ. Его семена богаты белком (до 25,8 \%), в них содержится до 8,2 \% жира, до 60 \% крахмала + сахара, 3 \% клетчатки [3- 
6]. Благодаря сбалансированному аминокислотному составу и большому содержанию метионина и триптофана по питательной ценности нут превосходит все другие зернобобовые культуры [7]. Энергетическая ценность нута составляет 329 ккал/100 г массы, что на 26 ккал больше, чем у гороха [8].

Лиманская В.Б., Шектыбаева Г.Х. [9] считают, что нут всегда являлся страховой культурой для Западного Казахстана. Поэтому, поиск новых более урожайных и ценных по комплексу хозяйственно-ценных признаков адаптированных сортов этой культуры в настоящее время является актуальной задачей и требует расширенных научных исследований.

В Западно-Казахстанской области площади посева этой культуры доходили до 3 тыс. га. За последние годы этот показатель варьирует в пределах от 300 до 500 га. С 2017 года планируется увеличение этого показателя до 1 тыс. га.

В условиях сухостепной зоны западного Казахстана, проведено широкое экологическое сортоиспытание сортов нута с целью выявления адаптированных и создания рабочей коллекции исходного материала для селекции. Среди выделенных, наибольший интерес представляют сорта и линии селекции Казахского НИИ земледелия и растениеводства. По комплексу признаков: урожайности, скороспелости, массе 1000 зерен выделены сорта ЕрСултан, Мальхотра, Волгоградский 25, Камила 1255, Икарда 1 и др. [10].

Метеоусловия 2015-2017 гг. были близки к среднемноголетним климатическим показателям, в 2015 году погодные условия были очень подходящими для оценки образцов на засухоустойчивость.

Материалом исследований послужили 19 номеров различного эколого-географического происхождения. 2 номера из Украины, 1 номер из Сирии, 1 номер из Марокко, 1 номер из Германии, 4 номера из Азербайджана и 9 номеров из Казахстана.

Посев поводили в оптимальные для культуры сроки, площадь делянки $25 \mathrm{~m}^{2}$, повторность трехкратная. Стандарт местный сорт Камила 1255 высевался через каждые 2 номера, междурядье 45 см и норма высева 400 тыс. всхожих зерен на 1 га.

Среднюю арифметическую, ее ошибку, дисперсионный анализ и коэффициент вариации определяли по Б.А. Доспехову (1979).

В сухостепной зоне Алматинской области (Карой) из структурного анализа номеров конкурсного сортоиспытания нута по хозяйственно - ценным признакам, выделяются номера, которые характеризуются высоким количеством бобов с растения (30-35 шт.) ТH45-1-01, F97-25/1, F98-30, Высокорослый, F97-121, F97-60, F02-04, F00-21, F97-14, F92-52, с высокой массой семян с растения (31-41 г) F00-21, F02-04, F97-14, F97-60, F92-52, с высокой массой 1000 семян (290-303 г): F97-14, Высокорослый, F02-04, F9760, F98-30 (табл. 1). 
Таблища 1 - Средние значения элементов продуктивности образцов нута конкурсного питомника, 2015-2017 гг.

\begin{tabular}{|c|c|c|c|c|c|c|c|}
\hline $\begin{array}{c}\text { Наименование } \\
\text { образца }\end{array}$ & 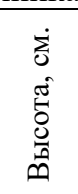 & 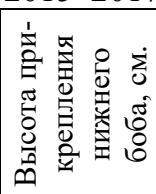 & 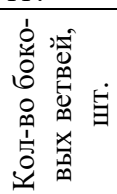 & 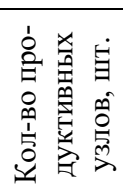 & 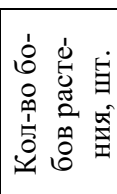 & 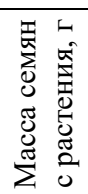 & 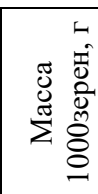 \\
\hline Ст. Камила 1255 & 50,3 & 23,7 & 2,3 & 16,0 & 16,7 & 16,7 & 237 \\
\hline Ezbsen Sponishe & 53,7 & 23,3 & 2,3 & 17,3 & 17,3 & 21,7 & 217 \\
\hline $30-Б$ & 44,3 & 26,0 & 2,0 & 15,3 & 15,3 & 19,3 & 243 \\
\hline $34-5$ & 47,5 & 27,0 & 2,0 & 12,0 & 12,0 & 14,0 & 260 \\
\hline F97-63 & 48,5 & 28,5 & 2,5 & 15,5 & 19,5 & 20,5 & 260 \\
\hline 13-Б & 42,3 & 23,3 & 2,0 & 12,3 & 12,3 & 12,3 & 263 \\
\hline F97-25/1 & 43,3 & 22,7 & 2,0 & 20,0 & 20,0 & 23,3 & 263 \\
\hline F92-52 & 56,0 & 32,0 & 4,5 & 36,0 & 37,5 & 41,0 & 265 \\
\hline $28-5$ & 48,0 & 30,0 & 3,0 & 19,7 & 19,7 & 25,3 & 267 \\
\hline F97-121 & 53,7 & 22,0 & 3,7 & 26,0 & 26,0 & 29,0 & 267 \\
\hline F00-21 & 59,0 & 41,5 & 3,5 & 23,5 & 30,0 & 31,0 & 270 \\
\hline 33-Б & 44,0 & 25,0 & 2,3 & 9,3 & 13,3 & 15,3 & 273 \\
\hline \begin{tabular}{|l|} 
TH45-1-01 \\
\end{tabular} & 49,3 & 29,3 & 2,0 & 15,3 & 20,0 & 21,3 & 277 \\
\hline F03-34-1 & 51,3 & 30,7 & 2,3 & 16,7 & 17,3 & 21,7 & 285 \\
\hline F97-14 & 58,5 & 42,0 & 4,0 & 29,5 & 32,0 & 32,0 & 290 \\
\hline Высокорослый & 50,7 & 32,0 & 1,3 & 24,3 & 24,3 & 26,0 & 297 \\
\hline F02-04 & 53,7 & 27,0 & 3,7 & 28,0 & 28,0 & 32,0 & 303 \\
\hline F97-60 & 55,0 & 30,0 & 4,0 & 27,5 & 27,5 & 36,0 & 300 \\
\hline F98-30 & 49,7 & 24,7 & 3,0 & 23,7 & 24,0 & 26,7 & 303 \\
\hline
\end{tabular}

В сухостепной зоне Алматинской области (Карой) за период 20152017 гг. по сравнению со стандартным сортом Камила 1255 в группе скороспелых и среднеспелых номеров выделено 3 номера, со средней урожайностью по годам 5,$1 ; 7,1 ; 7,9$ ц/га, которые достоверно превосходят по урожайности стандарт Камила 1255 на 1,3-3,0 ц/га (табл. 2).

В группе среднеспелых за 3 года исследований выделено 3 номера, средняя урожайность по годам выделенного образца составила 4,2; 5,2; 7,1 ц/га которые достоверно превосходят по урожайности стандарт Камила 1255 на 1,4 ц/га.

В группе среднепоздних, за 3 года исследований выделено 2 номера, средняя урожайность по годам выделенного образца составила 7,1; 6,2; 7,5 ц/га, которые достоверно превосходят по урожайности стандарт Камила 1255 на 2,2-2,3 ц/га. 
Таблища 2 - Урожайность выделившихся сортов нута питомника конкурсного сортоиспытания 2015-2017 гг.

\begin{tabular}{|c|c|c|c|c|c|c|c|c|c|}
\hline \multirow[b]{3}{*}{ Номер } & \multicolumn{9}{|c|}{ Год исследования } \\
\hline & \multicolumn{2}{|c|}{2015} & \multicolumn{2}{|c|}{2016} & \multicolumn{2}{|c|}{2017} & \multicolumn{3}{|c|}{ за три года } \\
\hline & 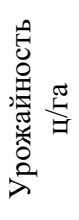 & 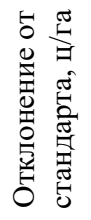 & 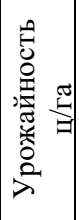 & 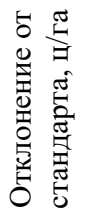 & 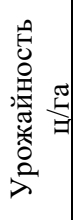 & 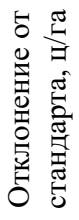 & 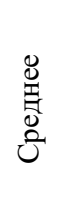 & 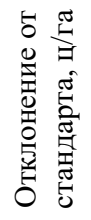 & 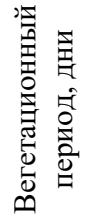 \\
\hline Ст. Камила 1255 & 4,0 & - & 4,2 & - & 6,0 & - & 4,7 & 0,0 & 83 \\
\hline \multicolumn{10}{|c|}{ Раннеспелые и среднеранние образцы (1 группа спелости) } \\
\hline F02-04 & 7,2 & 3,2 & 7,4 & 3,2 & 8,4 & 2,4 & 7,7 & 3,0 & 78 \\
\hline F97-121 & 3,9 & $-0,1$ & 7,0 & 2,8 & 8,2 & 2,2 & 6,3 & 1,6 & 78 \\
\hline TH45-1-01 & 4,1 & 0,1 & 6,8 & 2,6 & 7,1 & 1,1 & 6,0 & 1,3 & 80 \\
\hline \multicolumn{10}{|c|}{ Среднеспелые образцы (2 группа спелости) } \\
\hline 30-Б & 1,6 & $-2,4$ & 7,3 & 3,1 & 6,7 & 0,7 & 5,2 & 0,5 & 85 \\
\hline Высокорослый & 7,0 & 3,0 & 4,2 & $-0,0$ & 7,2 & 1,2 & 6,1 & 1,4 & 88 \\
\hline Ezbsen Sponishe & 4,0 & $-0,0$ & 4,2 & $-0,0$ & 7,5 & 1,5 & 5,2 & 0,5 & 88 \\
\hline \multicolumn{10}{|c|}{ Среднепоздние образцы (3 группа спелости) } \\
\hline 28-Б & 6,8 & 2,8 & 6,4 & 2,2 & 7,9 & 1,9 & 7,0 & 2,3 & 93 \\
\hline Мальхотра & 7,4 & 3,4 & 6,0 & 1,8 & 7,2 & 1,2 & 6,9 & 2,2 & 93 \\
\hline $\mathrm{HCP}_{095}$ & 1,0 & & 0,65 & & 0,85 & & & & \\
\hline
\end{tabular}

В среднем, по результатам изучения в питомнике конкурсного сортоиспытания в среднеранней ранней группе превышает по урожайности стандартного сорта Камила 1255, номер (F02-04) на 3,0 ц/га и номер (F97-121) на 1,6 ц/га. В среднеспелой группе номер (Высокорослый) на 1,4 ц/га.

В 2017 году передан на ГСИ сорт Сәтті. Урожайность на полуобеспеченной богаре за период 2015-2017 гг. 16,9 ц/га, а на жесткой богаре 7,6 ц/га. Содержание белка в зерне 31,9 \%, содержание масла 12,0 \%. Вегетационный период, наполуобеспеченной богаре, в среднем составил 90-97 дней, а на жесткой богаре в среднем составляет 78-88 дней. Сорт предназначен для возделывания на Юго-Востоке Казахстана и на неполивных землях Западного Казахстана.

\section{Список литературь}

1. Асатуллоев И.А. Исследование биохимического и ферментативного комплекса бобовых культур Таджикистана: автореферат на соискание ученой степени кандидата технических наук. - Москва, 2008. - 21 с.

2. Зотиков В.И. Зернобобовые культуры - источник растительного белка. - Орел: 
ГНУ ВНИИЗБК, 2010. - 268 с.

3. Столяров О.В., Федотов В.А., Демченко Н.И. Нут (Cicer arietinum L.): Монография. - Воронеж: Изд-во Воронежского государственного университета, 2004. - 256 с.

4. Muehlbauer F.J., Tullu A. Cicer arietinum L. NewCROP FactSHEET // http://www.hort.purdue.edu/newcrop/cropfactsheets/Chickpea.html, 1997.

5. Altaf N., Ahmad M.S. Chickpea (Cicer arietinum L.) // Biotechnology in Agriculture and Forestry. Vol. 10. Legumes and Oilseed Crops I. - Berlin Heidelberg: Springer-Verlag, 1990. - P. 100-113.

6. Saxena M.C. Problems and potential of chickpea production in nineties. In Chickpea in the nineties: Proceedings of the second International Workshop on the chickpea Improvement, 4-8 Dec 1989, ICRISAT Center, Patancheru, India, 1990.

7. Булынцев С.В., Балашов А.В. Генетические ресурсы мировых коллекций нута // Вестник РАСХН. - 2010. - №6. - С. 42-45.

8. Мартьянова А.И. Зернобобовые: распространение, закупки, химический состав и ценность // Зерновые культуры. - 2001. - №1. - С. 24-25.

9. Лиманская В.Б., Шектыбаева Г.Х. Результаты конкурсного сортоиспытания сортов нута в засушливых условиях Западно-Казахстанской области // Межд. научнопрак. конф. - 2017. - С. 176-178.

10. Лиманская В.Б. Культура нута для очень континентальных условий Западного Казахстана // Вавилосвкие чтения - 2015: Сборник статей Международной научнопрактической конференции, посвященной 128-й годовщине со дня рождения академика Н.И. Вавилова. - Саратов, 2015. - С. 224-225.

DOI 10.18699/GPB2020-08

\section{Идентификация генов устойчивости к стеблевой ржавчине в интрогрессивнх линиях яровой мягкой пшеницы селекции НИИСХ Юго-Востока с использованием молекулярных маркеров}

Баранова O.A. ${ }^{1}$ к.б.н., в.н.с.; Сибикеев C.H. ${ }^{2}$, Дружин A.E. ${ }^{2}$

${ }^{1}$ ФБНУ «Всероссийский научно-исследовательский институт защчить растений», Санкт-Петербург, Россия;

${ }^{2}$ ФГБНУ «Научно-исследовательский институт сельского хозяйства юговостока» (НИИСХ Юго-Востока), Саратов, Россия.

*e-mail: baranova_oa@mail.ru

В работе проанализированы 73 интрогрессивные линии яровой мягкой пшениць на устойчивость к льсогорской, казанской и омской популяциям стеблевой ржавчины и наличие известных $\mathrm{Sr}$ генов. В проанализированных интрогрессивных линиях идентифицированы гень Sr31/Lr26, Sr25/Lr19, Sr28, Sr22, Sr35, Sr57/Lr34 и Sr38/Lr37. Сочетание генов Sr31+Sr25 было идентифицировано у 6 линий (8,2\%). У семи линий идентифицировано сочетание генов $S r 25+S r 28$, у двух линий - Sr25+Sr35. B трех разных линиях идентифициированы сочетания генов - Sr25+Sr31+Sr57, 